\title{
Opgave- og skrivevejledning i klynger
}

\author{
Helle Merete Nordentoft, lektor ved Danmarks institut for Pæedagogik og \\ Uddannelse, Aarhus Universitet.
}

Hanne Nexø J ensen

Samfundslitteratur, 2015

128 sider

\section{ISBN 9788759319833}

Opgave- og skrivevejledning i klynger er en særdeles velkommen bog, da den griber ind i hjertet af de udfordringer, som kan udspille sig, når man vejleder kollektivt, og kommer med klare bud på, hvordan man kan vejlede i en klynge. Forskningen underbygger netop, at vejledning $\mathrm{i}$ et kollektivt forum er en udfordring for mange vejledere. En udfordring, som kan betyde to ting: 1) at de ikke påtager sig at vejlede i et kollektivt forum, og 2) når de gør det, udvikler "vejledningen" sig til mere at være en undervisningssituation end en vejledningssituation. Formålet med bogen er at konkretisere, hvordan undervisere og vejledere kan facilitere studerendes opgaveskriveproces i en klynge. Bogen er skrevet i et let tilgængeligt og flydende sprog og inddelt i 15 kapitler. Kapitel 1 er en introduktion til bogens indhold. Kapitel 2-4 uddyber de strukturelle og vejledningsmæssige rammer for skriveprocessen. Kapitel 5-12 følger på kronologisk vis skriveprocessen fra start til slut ift. de afsnit, som et eksamensprojekt bør indeholde. Endelig sammenfatter forfatteren de feedbackformer, som er beskrevet i bogens kapitler i kapitel 15.

Bogen spiller godt sammen med to andre centrale udgivelser ift. universitetspædagogik: Den gode opgave og den nyligt udkomne: Universitetspædagogik som en forenklet udgave af disse. Bogens styrke er klart, at den bevæger sig helt ind i skriveprocessens maskinrum og udfolder, hvad der er på spil. Fx illustrerer forfatteren, hvordan vejlederen kan vise de studerende, hvordan de kan arbejde med at undgå plagiat gennem den måde de citerer deres kilder på (s. 74). Forfatteren konkretiserer desuden et utal af måder, feedbackprocesser kan udfoldes på ift. den kontekst, vejlederen ønsker at bruge dem i.

Bogen er således relevant, men den er også udtryk for et ambitiøst projekt. Ifølge forfatteren skal den kunne fungere som en opslags-/håndbog, hvor kapitlerne kan læses hver for sig. I den forbindelse er det tanken, at de forskellige skematiske opsummeringer skal give vejlederen en oversigt, der er hurtig at gå til og at bruge, når han/hun skal vejlede den studerende igennem hele opgaveprocessen. Det er forfatterens tese, at undervisere og vejledere kan bidrage til at sikre en "effektiv" vejledning ved at "imødekomme studerendes vejledningsbehov gennem hele uddannelsen" (s. 10). Klyngevejledning kan desuden lære de studerende en processuel tænkning og gøre det muligt for dem "at skyde genvej til bedre opgaver" (s. 11).

Det er et dilemma på den ene side at skulle levere "effektiv undervisning" - hvad det så end betyder - og på den anden side at skulle være nuanceret pædagogisk og fagligt i de overvejelser, man gør sig som underviser og vejleder. I denne sammenhæng ser jeg, at bogens styrke samtidigt er dens svaghed: At væsentlige begrebsafklaringer og diskussioner er udeladt til fordel for en skematisering og forenkling af den kollektive vejlednings- 
og undervisningsproces. Fx uddybes det ikke særligt meget, hvordan ulemperne ved klyngevejledning, som skitseres på side 17, konkret kan spille ind og håndteres ift. de cases, som bogen præsenterer. Bogens læringsteoretiske afsæt understreger $\mathrm{fx}$, at deltagelse er en forudsætning for læring. Derfor ville det have været frugtbart med overvejelser ift., hvordan vejledere kan håndtere pædagogiske udfordringer ift. denne præmis, fx udfordringer med studerende, der stiller konfronterende spørgsmål, tavse studerende - eller studerende, som ikke bidrager aktivt til klyngens arbejde. Kapitlerne i bogen har karakter af at være opremsende gennem brugen af skemaer og kassemodeller ift., hvordan vejlederen/underviseren kan agere og facilitere læringsprocesser i en klynge. Et forhold, som forfatteren selv er opmærksom på og skriver, kan virke overvældende for nogle (s. 16).

Bogen rummer nogle begrebsmæssige uklarheder, som kan forvirre læseren ift. formålet med bogen. Fx er det ikke klart, hvad der karakteriserer en klynge til forskel fra fx en gruppe - og hvilken pædagogisk betydning det kan få. Desuden står der i kapitel 1 til forskel fra det, som bogens titel angiver, at bogen ikke kun tematiserer vejlednings- men også undervisningsforløb - uden dog at beskrive hvad forskellen er på undervisning og vejledning til trods for, at disse betegnelser bruges parallelt igennem hele bogen. Et introducerende kapitel kunne med fordel foretage disse begrebsmæssige afklaringer.

Der er eksempler på vejledning- og undervisning i klynger fra både humanistiske og naturvidenskabelig undervisningsområder. Disse eksempler forekommer rundt omkring $\mathrm{i}$ bogen uden, at der er en rød tråd i, hvornår hvilke eksempler bruges. Forfatteren har givetvis ønsket at vise, hvordan klyngeformen er en principiel undervisnings- og vejledningsform, som kan gå på tværs af fagfelter. Øvelsen er således at balancere det at få det principielle frem i klynge-vejledningsformen med det at vise, hvordan den konkret bruges i forskellige fagfelter. Sidstnæunte kan godt forvirre fokus ift. førstnæunte, da der er mange beskrivelser i en forholdsvis kort bog. Man kunne derfor have ønsket sig, at bogen havde benyttet to eksemplariske cases (en fra hvert hovedområde) ift., hvordan progressionen i klyngevejledningen kan udfoldes.

Når ovenstående er sagt, så har jeg allerede taget hul på flere af de anvisninger, som bogen giver ift. fx feedback i min egen undervisning og vejledning, og det har været meget givtigt. 